\title{
DNA methylation analysis in self-sampled brush material as a triage test in hrHPV-positive women
}

\begin{abstract}
A Boers ${ }^{1,7}, \mathrm{R} P$ Bosgraaf ${ }^{2,7}, \mathrm{R}$ W van Leeuwen ${ }^{1}$, E Schuuring $^{3}, \mathrm{D}$ A M Heideman ${ }^{4}, \mathrm{~L}$ F A G Massuger ${ }^{2}$, V M J Verhoef ${ }^{4}$, J Bulten ${ }^{5}$, W J G Melchers ${ }^{6}$, A G J van der Zee ${ }^{1}$, R L M Bekkers ${ }^{2}$ and G B A Wisman *,1

${ }^{1}$ Department of Gynaecologic Oncology, Cancer Research Center, University of Groningen, University Medical Center Groningen, Groningen, The Netherlands; ${ }^{2}$ Department of Obstetrics and Gynaecology, Radboud University Medical Center, Nijmegen, The Netherlands; ${ }^{3}$ Department of Pathology, Cancer Research Center, University of Groningen, University Medical Center Groningen, Groningen, The Netherlands; ${ }^{4}$ Department of Pathology, VU University Medical Center, Amsterdam, The Netherlands; ${ }^{5}$ Department of Pathology, Radboud University Medical Center, Nijmegen, The Netherlands and ${ }^{6}$ Department of Medical Microbiology, Radboud University Medical Center, Nijmegen, The Netherlands
\end{abstract}

Background: Primary high-risk human papillomavirus (hrHPV) testing in cervical cancer screening shows relatively low specificity, which makes triage testing necessary. In this study, DNA methylation analysis was compared with cytology for triage testing in hrHPV-positive women. Moreover, feasibility of DNA methylation analysis directly on brush-based self-sampled specimens was assessed.

Methods: Non-responding women from population-based screening were invited to self-collect a cervico-vaginal specimen for hrHPV testing; hrHPV-positive women were referred to a physician for triage liquid-based cytology. DNA methylation analysis was performed on 128 hrHPV-positive physician-collected triage samples and 50 matched brush self-samples with QMSP for C13ORF18, EPB41L3, JAM3 and TERT.

Results: In physician-taken triage material, DNA methylation analysis of JAM3 showed the highest combined specificity (88\%) and sensitivity (82\%) for detection of CIN3 +, whereas cytology showed a specificity of $48 \%$ and a sensitivity of $91 \%$. Out of 39 women with abnormal cytology and normal histology (false-positive by cytology), 87\% were negative for JAM3 and 90\% for C13ORF18 methylation. Agreement between DNA methylation analysis performed directly on the matched self-sampled material and physician-taken samples was 88\% for JAM3 $(\kappa=0.75, P<0.001)$ and $90 \%$ for C13ORF18 $(\kappa=0.77 ; P<0.001)$.

Conclusions: DNA methylation analysis as a triage test in hrHPV-positive women is an attractive alternative to cytology. Furthermore, DNA methylation is feasible directly on brush-based self-samplers and showed good correlation with matched physician-taken samples. Direct molecular triage on self-collected specimens could optimise the screening program, especially for non-responders, as this would eliminate the need for an additional physician-taken scraping for triage testing.

Cytomorphological assessment of cervical scrapings is still the most common method used in population-based cervical cancer screening. Several randomised trials have demonstrated that high-risk human papillomavirus (hrHPV) testing shows higher sensitivity for detecting (pre)malignant cervical lesions and consequently improves screening for cervical cancer (Mayrand

\footnotetext{
*Correspondence: Dr GBA Wisman; E-mail: g.b.a.wisman@umcg.nl

${ }^{7}$ These authors contributed equally to this work.
}

Received 18 February 2014; revised 17 June 2014; accepted 18 June 2014; published online 17 July 2014

(c) 2014 Cancer Research UK. All rights reserved 0007-0920/14 
et al, 2007; Arbyn et al, 2012; Rijkaart et al, 2012a; Ronco et al, 2013). However, hrHPV testing has a lower specificity compared with cytology, especially in younger women (Cuzick et al, 2006). To prevent unnecessary referrals to the gynaecologist, a triage test for hrHPV-positive women is necessary. Currently, cytological triage is the approach that is mostly advocated (Rijkaart et al, 2012b; Zorzi et al, 2013; Dijkstra et al, 2014). DNA methylation analysis of cancer-specific genes with quantitative methylationspecific PCR (QMSP) might be an alternative triage tool for early detection of cervical neoplasia (Lai et al, 2008; Overmeer et al, 2009; Yang et al, 2010). DNA promoter methylation of tumour suppressor genes is an early event in cervical carcinogenesis (Woodman et al, 2007; Yang et al, 2010). Several studies indeed reported that DNA methylation analysis could be a valuable objective triage tool for hrHPV-positive women (Hesselink et al, 2011; Overmeer et al, 2011; Eijsink et al, 2012). Scenario analysis comparing triage testing either by cytological examination or DNA methylation analysis after primary HPV screening showed that DNA methylation analysis as triage test will detect more CIN3 lesions, less carcinoma will be missed and more patients will be correctly referred to the gynaecologist (Eijsink et al, 2012). The recently published randomised controlled trial by Verhoef et al (2014) showed that detection of CIN2 + with methylation triage on self-samples directly in hrHPV-positive women was noninferior to cytology triage on physician-taken smears, leading to a shorter time to CIN2 + diagnosis, although referral was higher in the methylation triage group given the positive predictive value of this test being lower compared with cytology.

Apart from the efficacy of the screening test, the low participation rate is another aspect in population-based screening programs for cervical neoplasia that could be improved (Bekkers et al, 2006). About $35 \%$ of the women in the Netherlands do not respond to the screening invitation (referred to as non-responders). These women are at increased risk of developing cervical cancer, as more than $50 \%$ of the women diagnosed with cervical cancer had no history of participating in the population-based screening program (Peto et al, 2004; Bos et al, 2006). Introduction of selfsampling methods for hrHPV testing has shown an increase in participation up to $39 \%$ of these non-responders (Snijders et al, 2013). Furthermore, the response rate of the non-responders is significantly higher when offered a self-sampling device compared with a recall for regular cytology-based screening (Bais et al, 2007; Gok et al, 2010; Gok et al, 2012; Racey et al, 2013).

Recent studies have shown a high concordance of hrHPV test results between most self-collected samples and physician-taken cervical scrapings. Even more, vaginal self-samples and physiciantaken samples showed similar test accuracy in detecting CIN2 + lesions, especially when PCR-based HPV tests were used (Schmeink et al, 2011; Gok et al, 2012; Snijders et al, 2013; Arbyn et al, 2014). However, it is critical that follow-up and further management are acceptable to the participants, especially when participants are reluctant (Bosgraaf et al, 2013b). Therefore, direct triage testing on self-sampled material is preferred over an extra visit to a physician, but the concordance between cytology on selfobtained specimens $v s$ physician-taken samples is poor (Nobbenhuis et al, 2002; Garcia et al, 2003; Brink et al, 2006; Snijders et al, 2013). DNA methylation analysis directly performed on self-sampled material might solve this problem (Eijsink et al, 2011; Hesselink et al, 2014; Verhoef et al, 2014).

The aim of the present study was (1) to compare the performance of DNA methylation analysis with cytology as triage test on physician-taken samples of women who previously tested hrHPV-positive on a self-sampled specimen; (2) to analyse the feasibility of direct triage testing with DNA methylation analysis on brush-based self-sampled specimens and compare these results with DNA methylation results in the matched physician-taken samples.

\section{MATERIALS AND METHODS}

Study population. Women with a hrHPV-positive brush-based self-sampling result (Evalyn Brush, Rovers Medical devices B.V., Oss, The Netherlands) were selected for this pilot study. These women had participated in the PROHTECT-3B (PRotection by Offering HPV TEsting on Cervico-vaginal specimens Trial-3B) among non-responders of the Dutch screening program in the year 2008. The PROHTECT-3B study is a randomised controlled trial designed to determine whether the participation rate for a brushbased cervico-vaginal self-sampling device is non-inferior to the participation rate for a lavage-based self-sampling device (Bosgraaf et al, 2014). The study was ethically approved by the Ministry of Health (No 2010/WBO04). In short, a total of 35477 nonresponders of the regular cervical screening programme aged 3363 years were invited to participate. The self-sampling kit was sent to the home address of all eligible women. In total, 10027 women participated by returning self-sampled material to the laboratory for hrHPV testing (GP5 + /6 + PCR; EIA HPV GP HR kit; Diassay, Voorburg, The Netherlands). All women who tested hrHPV-negative were advised to participate in the next screening round. All hrHPV-positive women (8.3\%) were advised to comply with an additional cervical smear taken for cytology. All participating women gave informed consent.

Primary hrHPV testing of self-samplers. Upon arrival the dry self-sampled brushes were resuspended in $1.5 \mathrm{ml}$ of ThinPrep preservation medium (Hologic Inc., Marlborough, MA, USA). The vials were mixed for $3 \times 15 \mathrm{~s}$, stored overnight at $4{ }^{\circ} \mathrm{C}$ and again mixed for $2 \times 15 \mathrm{~s}$. For the primary hrHPV test, 1/10th of the selfsampled material was used. DNA was isolated with the Roche MagNA Pure MP 96 isolation station (Roche Diagnostics, Indianapolis, IN, USA) and hrHPV GP5 + /6 + -PCR testing was performed using the Diassay EIA HPV GP HR kit (Diassay), according to the instructions of the manufacturer (van den Brule et al, 2002).

Cytology triage testing. HrHPV-positive women underwent an additional cervical smear taken by a physician approximately 6 weeks later. These cervical smears were collected in $20 \mathrm{ml}$ Thinprep Preservcyt medium (Hologic Inc.) and cytomorphologically assessed according to the Dutch CISOE-A classification system, which can easily be translated into the Bethesda nomenclature (Bulk et al, 2004). Women with abnormal cytology results (threshold ASCUS) were referred to the gynaecologist where a biopsy specimen was taken; if the biopsy was abnormal $(\mathrm{CIN} 2+)$ they were treated according to the national guidelines in the Netherlands (Hanselaar, 2002). Women with normal cytology were re-invited after 6 months for a repeat cervical scraping for cytology and hrHPV co-testing. If one of these tests was abnormal, women were referred for colposcopy-directed biopsy; if there was a doublenegative test result, they were advised to attend the next regular screening round.

Sample selection for the current DNA methylation study. The triage physician-taken samples of PROHTECT-3B study were used to compare the performance of DNA methylation analysis $v s$ cytology as a triage test. Histology results were set as the gold standard. For this pilot study, a total of 128 women were selected based on different subgroups (Figure 1): women who were truepositive by cytology (abnormal cytology and abnormal histology, i.e., CIN2 + ); false-positive by cytology (abnormal cytology and normal histology, i.e., no CIN/CIN1); true-negative by cytology (twice normal cytology; at baseline and after 6 months) and falsenegative by cytology (baseline normal cytology and at 6 months abnormal histology, i.e., CIN2 + ). 


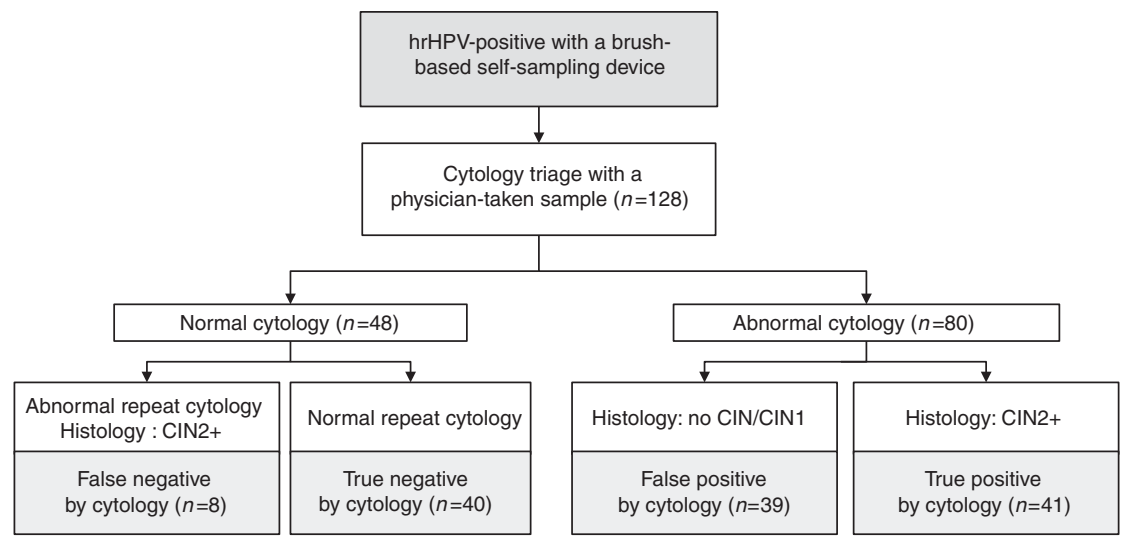

Figure 1. Study design.

To analyse the feasibility of direct triage testing with DNA methylation analysis on brush-based self-sampled material, a small group of $50 \mathrm{hrHPV}$-positive women were analysed for this study. These $50 \mathrm{hrHPV}$-positive women had subsequently undergone an additional cervical smear by a physician $\sim 6$ weeks later. About half of the group $(n=24)$ had an abnormal histological outcome $(\mathrm{CIN} 3+)$, and half of the group $(n=26)$ had a normal histological outcome $(\leqslant \mathrm{CIN} 2)$.

DNA extraction, bisulfite treatment and QMSP. For quantitative methylation-specific PCR, a new DNA isolation was performed using $5 \mathrm{ml}$ of the $20 \mathrm{ml}$ physician-taken specimen and the remaining material $(9 / 10$ th) of the self-sampled specimen. Genomic DNA was isolated by standard overnight proteinase $\mathrm{K}$ treatment, salt-chloroform extraction, and isopropanol precipitation (Eijsink et al, 2012) DNA quality was assessed according to the BIOMED-2 protocol (van Dongen et al, 2003). Sodium bisulfite treatment on isolated genomic DNA ( $1 \mu \mathrm{g}$ per sample) was performed according to the manufacturer's protocol of the EZ DNA methylation kit (Zymo Research Corp, Irvine, CA, USA).

Quantitative methylation-specific PCR was performed with bisulfite-treated DNA using an internal (FAM/TAMRA)-labelled hybridisation probe for quantitative analyses of four genes (C13ORF18, JAM3, EPB41L3 and TERT). Quantitative methylation-specific PCR conditions and primer and probe sequences are as described previously (Eijsink et al, 2011; Eijsink et al, 2012). To correct for DNA input, QMSP of the housekeeping gene $\beta$-actin was used. Quantitative methylation-specific PCR reactions were performed in a total volume of $20 \mu \mathrm{l}$, containing $10 \mu \mathrm{l}$ of $2 \times$ QuantiTect Probe Mastermix (Qiagen, Hilden, Germany), $600 \mathrm{~nm}$ of forward and reverse primers (Invitrogen, Carlsbad, CA, USA), $250 \mathrm{~nm}$ of hybridisation probe (IDT, Leuven, Belgium) and $50 \mathrm{ng}$ bisulphite-modified DNA. Each sample was analysed in triplicate in a 384-well plate using ABI PRISM 7900HT Sequence Detection System (Applied Biosystems, Life Technologies, Carlsbad, CA, USA). A pool of leukocyte DNA from healthy women was used as a negative control. As a positive control, in vitro methylated (by SssI enzyme) leukocyte DNA was used in each experiment. All amplification curves were visualised and scored without knowledge of clinical data. A DNA sample was considered methylated if at least 2 out of the 3 wells were methylation positive with a Ct-value below 50 and DNA input of at least $225 \mathrm{pg} \beta$-actin. Quantitative methylation-specific PCR values were adjusted for DNA input by expressing results as ratios between two absolute measurements ((average DNA quantity of methylated gene of interest/average DNA quantity for reference gene $\beta$-actin $\times 10000)($ Wisman et al, 2006).

Statistical analysis. Statistical analysis was performed using SPSS software package (SPSS 20, Chicago, IL, USA). Histology was set as the gold standard. Methylation levels per gene were compared with the severity of the underlying lesion by the Kruskall-Wallis test. Sensitivity and specificity were calculated with CIN2 + and $\mathrm{CIN} 3+$ as cutoff. Methylation levels per gene with $\mathrm{CIN} 3+$ as cutoff were visualised in a receiver-operating characteristic (ROC) curve. To compare sensitivity and specificity of triage testing by DNA methylation $v s$ triage testing by cytology on the same group of patients, the extended McNemar test, described by Hawass (1997) was executed. Concordance between the DNA methylation analysis of the Evalyn Brush self-samples and paired physiciantaken liquid-based samples was measured by Cohen's Kappa. Correlation of DNA methylation ratio in the paired physiciantaken liquid-based samples and Evalyn Brush self-samples was measured by the Spearman rank analysis; differences with a $P$ value $<0.05$ were considered statistically significant.

\section{RESULTS}

Performance of DNA methylation analysis in physician-taken samples. Liquid-based physician-taken samples of $128 \mathrm{hrHPV}$ positive women were used for QMSP of C13ORF18, JAM3, EPB41L3 and TERT. Methylation levels increased with the severity of the underlying lesion for all genes $(P<0.001)$ (data not shown). Table 1 shows the methylation positivity per subgroup. The patient group with abnormal cytology and CIN3 + lesions was methylation positive for C13ORF18 and JAM3 in 65\% (20/31) and 84\% $(26 / 31)$ of the cases, respectively, whereas the group with abnormal cytology and normal histology showed DNA methylation positivity in only $8 \%(4 / 49)$ and $16 \%(8 / 49)$ of these cases, respectively.

Table 2 shows the accuracy of DNA methylation analysis and cytology for detection of CIN2 + and CIN3 + . DNA methylation analysis of JAM3 showed the highest combined sensitivity (82\%) and specificity (88\%) for detection of CIN3 +, whereas cytology showed a specificity of $48 \%$ and a sensitivity of $91 \%$. Sensitivities for CIN3 + of JAM3 (82\%), EPB41L3 (88\%) and TERT (76\%) were comparable to cytology (91\%), whereas specificities for JAM3 $(88 \%)$ and C13ORF18 (91\%) were significantly better than for cytology $(48 \%)(P<0.001)$. For each marker, ROC curves for CIN3 + were computed (Figure 2). The areas under the curve were 0.855 for JAM3, 0.881 for EPB41L3 and 0.795 for C13ORF18 and TERT.

DNA methylation analysis on self-sampled material and its correlation with physician-taken material. From 50 patients with a liquid-based physician-taken sample also the matched original Evalyn Brush self-samples were used to perform the DNA methylation analysis. High-quality DNA could be retrieved from 49 brush devices. Performance of DNA methylation analysis directly on original self-sampled material showed again high 
Table 1. Methylation positivity in triage cytology per subgroup

\begin{tabular}{|c|c|c|c|c|c|c|c|c|}
\hline & & \multicolumn{2}{|c|}{$\begin{array}{l}\text { Abnormal cytology at } \\
\text { baseline ( } \geqslant \text { ASCUS) }\end{array}$} & \multicolumn{2}{|c|}{$\begin{array}{c}\text { Normal cytology (NILM) } \\
\text { at baseline }\end{array}$} & \multicolumn{3}{|c|}{$\begin{array}{c}\text { Abnormal cytology at baseline } \\
\text { ( } \geqslant \text { ASCUS) }\end{array}$} \\
\hline & $\begin{array}{l}\text { Normal cytology (NILM) } \\
\text { at baseline and follow-up }\end{array}$ & No CIN & CIN1 & CIN2 & CIN3 & CIN2 & CIN3 & Cancer \\
\hline C13ORF18 & $2 / 40(5 \%)$ & $1 / 18(6 \%)$ & $3 / 21(14 \%)$ & $2 / 5(40 \%)$ & $2 / 3(67 \%)$ & $0 / 10(0 \%)$ & $13 / 22(59 \%)$ & 7/9 (78\%) \\
\hline JAM3 & $3 / 40(8 \%)$ & $2 / 18(11 \%)$ & $3 / 21(14 \%)$ & $0 / 5(0 \%)$ & $2 / 3(67 \%)$ & $3 / 10(30 \%)$ & $17 / 22(77 \%)$ & $9 / 9$ (100\%) \\
\hline EPB41L3 & $10 / 40(25 \%)$ & $10 / 18(56 \%)$ & $14 / 21(67 \%)$ & $0 / 5(0 \%)$ & $2 / 3(67 \%)$ & $3 / 10(30 \%)$ & $19 / 22(86 \%)$ & $9 / 9(100 \%)$ \\
\hline TERT & $13 / 40(33 \%)$ & 9/18 (50\%) & $8 / 21(38 \%)$ & $4 / 5(80 \%)$ & $2 / 3(67 \%)$ & $4 / 10(40 \%)$ & $15 / 22(68 \%)$ & 9/9 (100\%) \\
\hline
\end{tabular}

Abbreviations: ASCUS = atypical squamous cells of undetermined significance; NILM=negative for intraepithelial lesions or malignancies

Table 2. Sensitivity and specificity of methylation markers and cytology on physician-taken material for CIN2 + and CIN3 $+(n=128)$

\begin{tabular}{|c|c|c|c|c|}
\hline \multirow[b]{2}{*}{ Test } & Sensitivity $(95 \% \mathrm{Cl})$ & Specificity $(95 \% \mathrm{Cl})$ & Sensitivity $(95 \% \mathrm{Cl})$ & Specificity $(95 \% \mathrm{Cl})$ \\
\hline & \multicolumn{2}{|c|}{$\mathrm{CIN} 2+$} & \multicolumn{2}{|c|}{ CIN3+ } \\
\hline C13ORF18 & $49 \%(34.4-63.7)$ & $92 \%(84.2-97.1)$ & $65 \%(46.5-80.2)$ & $91 \%(83.9-96.2)$ \\
\hline JAM3 & $63 \%(48.3-76.6)$ & $90 \%(81.0-95.5)$ & $82 \%(65.5-93.2)$ & $88 \%(80.0-94.0)$ \\
\hline EPB41L3 & $67 \%(52.5-80.0)$ & $57 \%(45.3-68.1)$ & $88 \%(72.5-96.6)$ & $61 \%(50.0-70.6)$ \\
\hline TERT & $69 \%(54.6-81.7)$ & $62 \%(50.4-72.7)$ & $76 \%(58.8-89.2)$ & $60 \%(49.0-69.6)$ \\
\hline Abnormal cytology ( $\geqslant$ ASCUS) & $84 \%(70.3-92.7)$ & $51 \%(39.1-62.1)$ & $91 \%(76.3-98.0)$ & $48 \%(37.5-58.4)$ \\
\hline
\end{tabular}

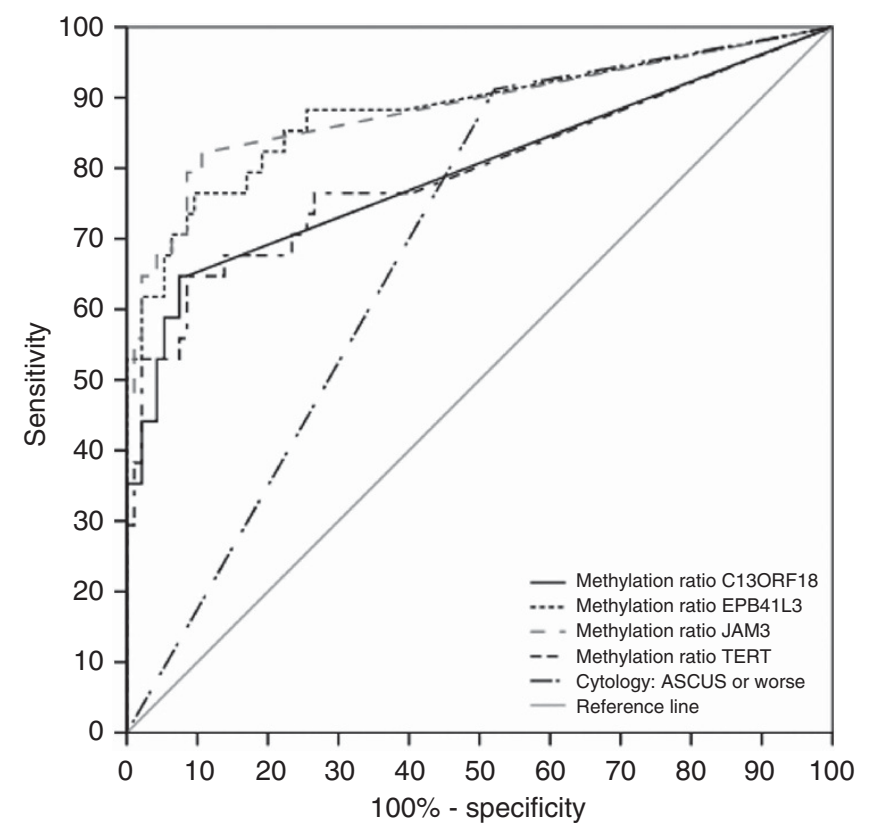

Figure 2. ROC curves for methylation ratio of C13ORF18, JAM3, EPB41L3 and TERT for CIN3 +.

specificities for JAM3 and C13ORF18 (both 96\%), with corresponding sensitivities of $71 \%$ and $54 \%$ for CIN3 +, respectively, (Table 3). Also EPB41L3 showed high specificity (88\%) with corresponding high sensitivity (79\%). The agreement between the methylation outcome of the Evalyn Brush self-sampled specimen
Table 3. Sensitivity and specificity of methylation markers on brush-based self-sampled material for CIN3 $+(n=49)$

\begin{tabular}{|l|c|c|}
\hline Test & Sensitivity (95\% Cl) & Specificity (95\% Cl) \\
\hline C13ORF18 & $54 \%(35-72 \%)$ & $96 \%(80-99 \%)$ \\
\hline JAM3 & $71 \%(51-85 \%)$ & $96 \%(80-99 \%)$ \\
\hline EPB41L3 & $79 \%(60-91 \%)$ & $88 \%(70-96 \%)$ \\
\hline TERT & $54 \%(35-72 \%)$ & $80 \%(61-91 \%)$ \\
\hline \multicolumn{2}{|l}{ Abbreviation: Cl= confidence interval. } \\
\hline
\end{tabular}

and the liquid-based samples taken by the physician was $90 \%$ for C13ORF18 $(\kappa=0.77, \quad P<0.001), 88 \%$ for JAM3 $(\kappa=0.75$, $P<0.001), 80 \%$ for EPB41L3 $(\kappa=0.59, P<0.001)$ and $71 \%$ for TERT $(\kappa=0.41, P=0.003)$. Comparing the methylation ratios between the matched self- and physician-taken samples showed again a very high concordance $(P<0.001)$, with the best results for C13ORF18 $(r=0.82, P<0.001)$, EPB41L3 $(r=0.84, P<0.001)$ and JAM3 ( $r=0.89, P<0.001)$ methylation (Figure 3$)$.

\section{DISCUSSION}

This study shows for the first time that DNA methylation analysis is feasible on brush-based self-sampled cervico-vaginal material. The concordance between DNA methylation analysis on selfsampled material and physician-taken samples in this study was high. Furthermore, the clinical performance of DNA methylation analysis as triage test on both hrHPV-positive physician-taken samples and self-collected samples was good, with high specificity, 

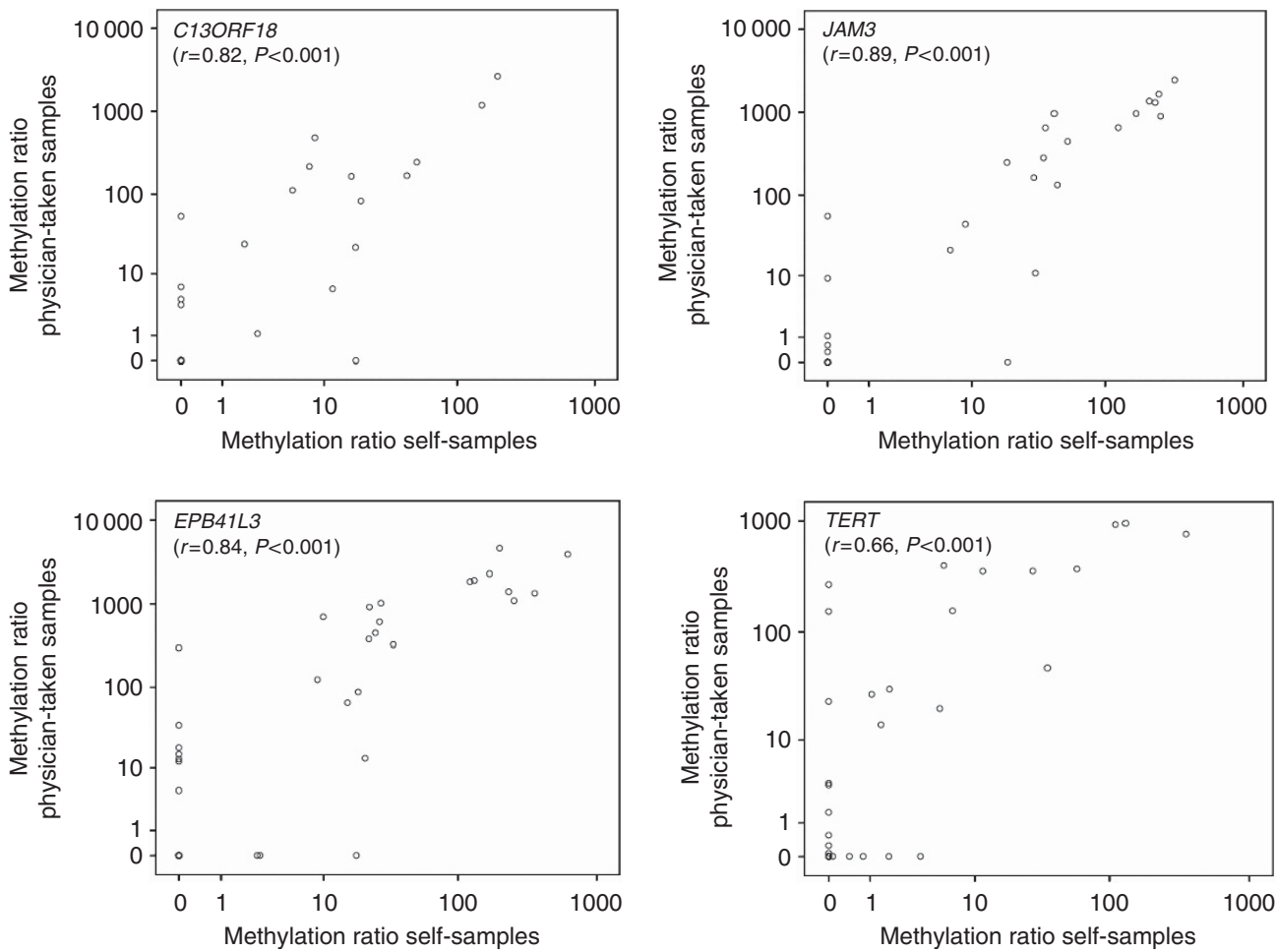

Figure 3. Methylation ratio of C13ORF18, JAM3, EPB41L3 and TERT as determined in self-sampled material and in matched physician-taken triage material.

particularly for C13ORF18 and JAM3, and moderate to high sensitivity in the studied series.

The sensitivity of hrHPV assays evaluated in primary screening appeared consistently high for detection of CIN3 + (Arbyn et al, 2012). In primary screening this higher clinical sensitivity may lead to earlier diagnosis of high-grade cervical lesions and prevent cervical cancer (Ronco et al, 2013). However, hrHPV screening is less specific, especially for young women, resulting in a relatively high false-positive rate (Cuzick et al, 2006). With a triage test, specificity can be improved and this results in fewer referrals for colposcopy, reduction of overtreatment and anxiety of false-positive women and also reduces the costs (Bosgraaf et al, 2013a). Cytology as triage test, as suggested in the new Dutch HPV-screening program, will ensure that most women with underlying CIN2 + lesions are correctly referred for colposcopy (Ministry of Health, Welfare and Sport, 2013). However, in this study we showed that specificity could be further improved by the use of DNA methylation.

The high-sensitivity and low-specificity results of cytology found in this study might be explained by the cytologist's awareness of the HPV-positive results. Furthermore, the sample selection was based on different subgroups, and is therefore not representative for the whole group. Nonetheless, in these specified selected subgroups, our findings point to the methylation test as an attractive alternative to cytology as a triage test. The advantage of DNA methylation analysis as a triage test on cervical smear in comparison with cytology is that it is an objective, nonmorphological test. In this study, we showed a high specificity of C13ORF18 and JAM3 methylation for CIN3 + , and a moderate to high sensitivity for C13ORF18, JAM3 and EPB41L3. In addition, we showed in the group 'false-positive by cytology' (abnormal cytology and normal histology) that methylation positivity was very low, which in a screening context would result in a reduction of referrals of false-positive women to the gynaecologist. In addition, the methylation test detected out of 3 women with a CIN3 lesion who were missed with cytology triage testing.
DNA methylation analysis in self-sampled cervico-vaginal brush specimens showed high specificity and moderate to high sensitivity for detection of $\mathrm{CIN} 3+$ lesions. The concordance between DNA methylation analysis on the self-sampled material and the corresponding physician-taken sample taken $\sim 6$ weeks later from the same patient was high, which supports reliability of the methylation test in the self-sampled material. An advantage of DNA methylation analysis performed directly on self-sampled material is that it eliminates the need for an additional cervical smear. As a result, loss to follow-up could decrease, especially in the non-responder group. Large population-based studies in nonresponders of the regular cervical cancer screening showed that about $10 \%$ of the HPV-positive women did not visit their physician for triage cytology (Gok et al, 2010; Gok et al, 2012).

Previously, we evaluated the same four genes (C13ORF18, JAM3, EPB41L3 and TERT) by DNA methylation analysis on selfsampled material obtained by a lavage device (Eijsink et al, 2011). In the current study, we showed representative methylation results for these four genes, and we also showed that DNA methylation analysis on self-samples by a dry cervical brush device can be used as well. The use of dry brush devices may have advantages over cervico-vaginal lavage devices, as brushes can be transported and stored dry, whereas liquid specimens are less convenient for sending by regular mail (van Baars et al, 2012). But above all, both devices are not suitable for cytological examination (Snijders et al, 2013). Therefore, DNA methylation is more suitable for triage testing after hrHPV self-sampling compared with cytology. In the current study, we analysed four genes, previously validated (Eijsink et al, 2011; Eijsink et al, 2012), of which some showed already better specificity compared with cytology without losing sensitivity to detect CIN3 + . The advantage of using these particular genes is that setting a cutoff value is not needed. If the PCR product was negative (i.e., no amplification of specific product), the sample was called negative and any ratio above zero for two PCR products (analysed in triplicate) was called positive. This unique feature of the selected genes makes it an objective easy to interpret test. 
Furthermore, also other groups describe some of these genes (e.g., EPB41L3) as predictors for CIN2/3 lesions (Brentnall et al, 2014; Vasiljevic et al, 2014). Addition of other potential markers reported (Wentzensen et al, 2009; Lai et al, 2010; Overmeer et al, 2011; Lendvai et al, 2012; Bierkens et al, 2013; Verhoef et al, 2014) or identification of even better differentially methylated genes by genome-wide methods could even further improve the diagnostic accuracy of DNA methylation in the future.

Although the present study included a relatively small number of samples and comprised a selected series, it had several strengths. The primary HPV tests as well as DNA methylation analysis were both performed on the same self-sampled material. In addition, the matched physician-taken liquid-based cytology samples were available for DNA methylation analysis and this allowed direct comparison between DNA methylation analyses on self-samplers $v s$ physician-taken samples. A limitation of our study is the lack of histology; the medical ethics committee did not allow to take cervical biopsies in women with normal triage cytology and normal follow-up cytology after 6 months, which may lead to an under- or overestimation of the exact performance of DNA methylation in the triage of these screening results.

In conclusion, DNA methylation analysis is feasible on brush-based self-sampled material, and its diagnostic performance as triage test for hrHPV-positive women showed similar results as DNA methylation analysis on physician-taken samples. Direct methylation analysis on self-sampled material could be an important step forward in optimising the screening programme, as this would eliminate the need for an extra physician-taken cervical scraping for triage testing. In addition, owing to its high specificity it would reduce the number of falsepositive women referred to the gynaecologist. Our data indicate that the detection of cervical neoplasia by DNA methylation analysis in cervico-vaginal brush specimens warrants further exploration of its use in large population-based prospective cohort studies.

\section{REFERENCES}

Arbyn M, Ronco G, Anttila A, Meijer CJ, Poljak M, Ogilvie G, Koliopoulos G, Naucler P, Sankaranarayanan R, Peto J (2012) Evidence regarding human papillomavirus testing in secondary prevention of cervical cancer. Vaccine 30(Suppl 5): F88-F99.

Arbyn M, Verdoodt F, Snijders PJ, Verhoef VM, Suonio E, Dillner L, Minozzi S, Bellisario C, Banzi R, Zhao FH, Hillemanns P, Anttila A (2014) Accuracy of human papillomavirus testing on self-collected versus clinician-collected samples: a meta-analysis. Lancet Oncol 15: 172-183.

Bais AG, van Kemenade FJ, Berkhof J, Verheijen RH, Snijders PJ, Voorhorst F, Babovic M, van Ballegooijen M, Helmerhorst TJ, Meijer CJ (2007) Human papillomavirus testing on self-sampled cervicovaginal brushes: an effective alternative to protect nonresponders in cervical screening programs. Int J Cancer 120: 1505-1510.

Bekkers RL, Meijer CJ, Massuger LF, Snijders PJ, Melchers WJ (2006) Effects of HPV detection in population-based screening programmes for cervical cancer; a Dutch moment. Gynecol Oncol 100: 451-454.

Bierkens M, Hesselink AT, Meijer CJ, Heideman DA, Wisman GB, van der Zee AG, Snijders PJ, Steenbergen RD (2013) CADM1 and MAL promoter methylation levels in hrHPV-positive cervical scrapes increase proportional to degree and duration of underlying cervical disease. Int $J$ Cancer 133: 1293-1299.

Bos AB, Rebolj M, Habbema JD, van Ballegooijen M (2006) Nonattendance is still the main limitation for the effectiveness of screening for cervical cancer in the Netherlands. Int J Cancer 119: 2372-2375.

Bosgraaf RP, Mast PP, Struik-van der Zanden PH, Bulten J, Massuger LF, Bekkers RL (2013a) Overtreatment in a see-and-treat approach to cervical intraepithelial lesions. Obstet Gynecol 121: 1209-1216.

Bosgraaf RP, Siebers AG, De Hullu JA, Massuger LF, Bulten J, Bekkers RL, Melchers WJ (2013b) The current position and the future perspectives of cervical cancer screening. Expert Rev Anticancer Ther 14: 75-92.
Bosgraaf RP, Verhoef VM, Massuger LF, Siebers AG, Bulten J, de Kuyper-de Ridder GM, Meijer CJ, Snijders PJ, Heideman DA, IntHout J, van Kemenade FJ, Melchers WJ, Bekkers RL (2014) Comparative performance of novel self-sampling methods in detecting high-risk human papillomavirus in 30130 women not attending cervical screening. Int J Cancer; e-pub ahead of print 13 June 2014; doi:10.1002/ ijc. 29026.

Brentnall AR, Vasiljevic N, Scibior-Bentkowska D, Cadman L, Austin J, Szarewski A, Cuzick J, Lorincz AT (2014) A DNA methylation classifier of cervical precancer based on human papillomavirus and human genes. Int J Cancer; e-pub ahead of print 18 February 2014; doi:10.1002/ijc.28790.

Brink AA, Meijer CJ, Wiegerinck MA, Nieboer TE, Kruitwagen RF, van Kemenade F, Fransen Daalmeijer N, Hesselink AT, Berkhof J, Snijders PJ (2006) High concordance of results of testing for human papillomavirus in cervicovaginal samples collected by two methods, with comparison of a novel self-sampling device to a conventional endocervical brush. J Clin Microbiol 44: 2518-2523.

Bulk S, Van Kemenade FJ, Rozendaal L, Meijer CJ (2004) The Dutch CISOEA framework for cytology reporting increases efficacy of screening upon standardisation since 1996. J Clin Pathol 57: 388-393.

Cuzick J, Clavel C, Petry KU, Meijer CJ, Hoyer H, Ratnam S, Szarewski A, Birembaut P, Kulasingam S, Sasieni P, Iftner T (2006) Overview of the European and North American studies on HPV testing in primary cervical cancer screening. Int J Cancer 119: 1095-1101.

Dijkstra MG, van Niekerk D, Rijkaart DC, van Kemenade FJ, Heideman DA, Snijders PJ, Meijer CJ, Berkhof J (2014) Primary hrHPV DNA testing in cervical cancer screening: how to manage screen-positive women? A POBASCAM trial substudy. Cancer Epidemiol Biomarkers Prev 23: 55-63.

Eijsink JJ, Lendvai A, Deregowski V, Klip HG, Verpooten G, Dehaspe L, de Bock GH, Hollema H, van Criekinge W, Schuuring E, van der Zee AG, Wisman GB (2012) A four-gene methylation marker panel as triage test in high-risk human papillomavirus positive patients. Int J Cancer 130: 1861-1869.

Eijsink JJ, Yang N, Lendvai A, Klip HG, Volders HH, Buikema HJ, van Hemel BM, Voll M, Coelingh Bennink HJ, Schuuring E, Wisman GB, van der Zee AG (2011) Detection of cervical neoplasia by DNA methylation analysis in cervico-vaginal lavages, a feasibility study. Gynecol Oncol 120: 280-283.

Garcia F, Barker B, Santos C, Brown EM, Nuno T, Giuliano A, Davis J (2003) Cross-sectional study of patient- and physician-collected cervical cytology and human papillomavirus. Obstet Gynecol 102: 266-272.

Gok M, Heideman DA, van Kemenade FJ, Berkhof J, Rozendaal L, Spruyt JW, Voorhorst F, Belien JA, Babovic M, Snijders PJ, Meijer CJ (2010) HPV testing on self collected cervicovaginal lavage specimens as screening method for women who do not attend cervical screening: cohort study. BMJ 340: c1040.

Gok M, van Kemenade FJ, Heideman DA, Berkhof J, Rozendaal L, Spruyt JW, Belien JA, Babovic M, Snijders PJ, Meijer CJ (2012) Experience with high-risk human papillomavirus testing on vaginal brush-based selfsamples of non-attendees of the cervical screening program. Int J Cancer 130: 1128-1135.

Hanselaar AG (2002) Criteria for organized cervical screening programs. Special emphasis on The Netherlands program. Acta Cytol 46: 619-629.

Hawass NE (1997) Comparing the sensitivities and specificities of two diagnostic procedures performed on the same group of patients. Br J Radiol 70: 360-366.

Hesselink AT, Heideman DA, Steenbergen RD, Coupe VM, Overmeer RM, Rijkaart D, Berkhof J, Meijer CJ, Snijders PJ (2011) Combined promoter methylation analysis of CADM1 and MAL: an objective triage tool for high-risk human papillomavirus DNA-positive women. Clin Cancer Res 17: 2459-2465.

Hesselink AT, Heideman DA, Steenbergen RD, Gok M, van Kemenade FJ, Wilting SM, Berkhof J, Meijer CJ, Snijders PJ (2014) Methylation marker analysis of self-sampled cervico-vaginal lavage specimens to triage highrisk HPV-positive women for colposcopy. Int J Cancer 135: 880-886.

Lai HC, Lin YW, Huang RL, Chung MT, Wang HC, Liao YP, Su PH, Liu YL, Yu MH (2010) Quantitative DNA methylation analysis detects cervical intraepithelial neoplasms type 3 and worse. Cancer 116: 4266-4274.

Lai HC, Lin YW, Huang TH, Yan P, Huang RL, Wang HC, Liu J, Chan MW, Chu TY, Sun CA, Chang CC, Yu MH (2008) Identification of novel DNA methylation markers in cervical cancer. Int J Cancer 123: 161-167.

Lendvai A, Johannes F, Grimm C, Eijsink JJ, Wardenaar R, Volders HH, Klip HG, Hollema H, Jansen RC, Schuuring E, Wisman GB, 
van der Zee AG (2012) Genome-wide methylation profiling identifies hypermethylated biomarkers in high-grade cervical intraepithelial neoplasia. Epigenetics 7: 1268-1278.

Mayrand MH, Duarte-Franco E, Rodrigues I, Walter SD, Hanley J, Ferenczy A, Ratnam S, Coutlee F, Franco EL. Canadian Cervical Cancer Screening Trial Study Group (2007) Human papillomavirus DNA versus Papanicolaou screening tests for cervical cancer. N Engl J Med 357: $1579-1588$

Ministry of Health, Welfare and Sport (2013) [Letter to the House of Representatives of the Dutch parliament: Improvement of the Dutch cervical cancer screening].

Nobbenhuis MA, Helmerhorst TJ, van den Brule AJ, Rozendaal L, Jaspars LH, Voorhorst FJ, Verheijen RH, Meijer CJ (2002) Primary screening for high risk HPV by home obtained cervicovaginal lavage is an alternative screening tool for unscreened women. J Clin Pathol 55: 435-439.

Overmeer RM, Henken FE, Bierkens M, Wilting SM, Timmerman I, Meijer CJ, Snijders PJ, Steenbergen RD (2009) Repression of MAL tumour suppressor activity by promoter methylation during cervical carcinogenesis. J Pathol 219: 327-336.

Overmeer RM, Louwers JA, Meijer CJ, Van Kemenade FJ, Hesselink AT, Daalmeijer NF, Wilting SM, Heideman DA, Verheijen RH, Zaal A, Marchien VB, Berkhof J, Snijders PJ, Steenbergen RD (2011) Combined CADM1 and MAL promoter methylation analysis to detect (pre-)malignant cervical lesions in high-risk HPV-positive women. Int J Cancer 129: 2218-2225.

Peto J, Gilham C, Fletcher O, Matthews FE (2004) The cervical cancer epidemic that screening has prevented in the UK. Lancet 364: 249-256.

Racey CS, Withrow DR, Gesink D (2013) Self-collected HPV testing improves participation in cervical cancer screening: a systematic review and meta-analysis. Can J Public Health 104: e159-e166.

Rijkaart DC, Berkhof J, Rozendaal L, van Kemenade FJ, Bulkmans NW, Heideman DA, Kenter GG, Cuzick J, Snijders PJ, Meijer CJ (2012a) Human papillomavirus testing for the detection of high-grade cervical intraepithelial neoplasia and cancer: final results of the POBASCAM randomised controlled trial. Lancet Oncol 13: 78-88.

Rijkaart DC, Berkhof J, van Kemenade FJ, Coupe VM, Hesselink AT, Rozendaal L, Heideman DA, Verheijen RH, Bulk S, Verweij WM, Snijders PJ, Meijer CJ (2012b) Evaluation of 14 triage strategies for HPV DNA-positive women in population-based cervical screening. Int $J$ Cancer 130: $602-610$.

Ronco G, Dillner J, Elfstrom KM, Tunesi S, Snijders PJ, Arbyn M, Kitchener H, Segnan N, Gilham C, Giorgi-Rossi P, Berkhof J, Peto J, Meijer CJ. the International HPV screening working group (2013) Efficacy of HPV-based screening for prevention of invasive cervical cancer: follow-up of four European randomised controlled trials. Lancet 383: 524-532.

Schmeink CE, Bekkers RL, Massuger LF, Melchers WJ (2011) The potential role of self-sampling for high-risk human papillomavirus detection in cervical cancer screening. Rev Med Virol 21: 139-153.

Snijders PJ, Verhoef VM, Arbyn M, Ogilvie G, Minozzi S, Banzi R, van Kemenade FJ, Heideman DA, Meijer CJ (2013) High-risk HPV testing on self-sampled versus clinician-collected specimens: a review on the clinical accuracy and impact on population attendance in cervical cancer screening. Int J Cancer 132: 2223-2236. van Baars R, Bosgraaf RP, ter Harmsel BW, Melchers WJ, Quint WG, Bekkers RL (2012) Dry storage and transport of a cervicovaginal self-sample by use of the Evalyn Brush, providing reliable human papillomavirus detection combined with comfort for women. J Clin Microbiol 50: 3937-3943.

van den Brule AJ, Pol R, Fransen-Daalmeijer N, Schouls LM, Meijer CJ, Snijders PJ (2002) GP5 + /6 + PCR followed by reverse line blot analysis enables rapid and high-throughput identification of human papillomavirus genotypes. J Clin Microbiol 40: 779-787.

van Dongen JJ, Langerak AW, Bruggemann M, Evans PA, Hummel M, Lavender FL, Delabesse E, Davi F, Schuuring E, Garcia-Sanz R, van Krieken JH, Droese J, Gonzalez D, Bastard C, White HE, Spaargaren M, Gonzalez M, Parreira A, Smith JL, Morgan GJ, Kneba M, Macintyre EA (2003) Design and standardization of PCR primers and protocols for detection of clonal immunoglobulin and T-cell receptor gene recombinations in suspect lymphoproliferations: report of the BIOMED-2 Concerted Action BMH4-CT98-3936. Leukemia 17: 2257-2317.

Vasiljevic N, Scibior-Bentkowska D, Brentnall AR, Cuzick J, Lorincz AT (2014) Credentialing of DNA methylation assays for human genes as diagnostic biomarkers of cervical intraepithelial neoplasia in high-risk HPV positive women. Gynecol Oncol 132: 709-714.

Verhoef VM, Bosgraaf RP, van Kemenade FJ, Rozendaal L, Heideman DA, Hesselink AT, Bekkers RL, Steenbergen RD, Massuger LF, Melchers WJ, Bulten J, Overbeek LI, Berkhof J, Snijders PJ, Meijer CJ (2014) Triage by methylation-marker testing versus cytology in women who test HPV-positive on self-collected cervicovaginal specimens (PROHTECT-3): a randomised controlled non-inferiority trial. Lancet Oncol 15: 315-322.

Wentzensen N, Sherman ME, Schiffman M, Wang SS (2009) Utility of methylation markers in cervical cancer early detection: appraisal of the state-of-the-science. Gynecol Oncol 112: 293-299.

Wisman GB, Nijhuis ER, Hoque MO, Reesink-Peters N, Koning AJ, Volders HH, Buikema HJ, Boezen HM, Hollema H, Schuuring E, Sidransky D, van der Zee AG (2006) Assessment of gene promoter hypermethylation for detection of cervical neoplasia. Int J Cancer 119: 1908-1914.

Woodman CB, Collins SI, Young LS (2007) The natural history of cervical HPV infection: unresolved issues. Nat Rev Cancer 7: 11-22.

Yang N, Nijhuis ER, Volders HH, Eijsink JJ, Lendvai A, Zhang B, Hollema H, Schuuring E, Wisman GB, van der Zee AG (2010) Gene promoter methylation patterns throughout the process of cervical carcinogenesis. Cell Oncol 32: 131-143.

Zorzi M, Del Mistro A, Farruggio A, de'Bartolomeis L, Frayle-Salamanca H, Baboci L, Bertazzo A, Cocco P, Fedato C, Gennaro M, Marchi N, Penon MG, Cogo C, Ferro A (2013) Use of a high-risk human papillomavirus DNA test as the primary test in a cervical cancer screening programme: a population-based cohort study. BJOG 120: 1260-1267.

This work is published under the standard license to publish agreement. After 12 months the work will become freely available and the license terms will switch to a Creative Commons AttributionNonCommercial-Share Alike 3.0 Unported License. 